\title{
TRANSFORMATION OF FIVE GRAPE ROOTSTOCKS WITH PLANT VIRUS GENES AND A virE2 GENE FROM AGROBACTERIUM TUMEFACIENS
}

\author{
B. XUE, K.-S. LING, C. L. REID, S. KRASTANOVA, M. SEKIYA, E. A. MOMOL, S. SÜLE, J. MOZSAR, D. GONSALVES, \\ AND T. J. BURR'
}

Department of Plant Pathology, Cornell University, New York State Agricultural Experiment Station, Geneva, New York 14456

(B. X., K.S. L., C. L. R., S. K., M. S., E. A. M., D. G., T. J. B.), and Plant Protection Institute of the Hungarian Academy of Sciences, Budapest 1525, P.O. Box 102, Hungary (S. S., J. M.)

(Received 13 April 1998; accepted 17 February 1999; editor, Michael R. Becwar)

\section{SUMMARY}

To facilitate the development of transgenic grapevines that are resistant to grapevine fanleaf virus (GFLV), grapevine leafroll-associated closterovirus (GLRaV-3) and crown gall diseases, we developed a rapid system for regenerating rootstocks: Couderc 3309, Vitis riparia 'Gloire de Montpellier', Teleki 5C, Millardet et De Grasset 101-14, and 110 Richter via somatic embryogenesis. Embryo culture and grape regeneration were accomplished with four media. Embryogenic calluses from anthers were induced in the initiation medium [MS basic medium containing 20 g sucrose per L, $1.1 \mathrm{mg} 2,4$ dichlorophenoxyacetic acid (2,4-D) per L, $0.2 \mathrm{mg} \mathrm{N} \mathrm{N}^{6}$-benzyladenine (BA) per L, and $0.8 \%$ Noble agar]. The percentage of anthers that developed into embryogenic calli ranged from 2 to $16.3 \%$ depending on the rootstock. Calluses with early globular stage embryos were cocultivated with Agrobacterium tumefaciens strain C58Z707 containing the gene constructs of interest. The genes were sense-oriented translatable and antisense coat protein genes from GFLV and GLRaV-3, a truncated HSP90-related gene of GLRaV-3 (43K), and a virE2 del B gene from A. tumefaciens strain C58. Twenty independent transformation experiments were performed on five rootstocks. After 3-4 mo. under kanamycin selection, secondary embryos were recovered on differentiation medium (1/2 MS salts with $10 \mathrm{~g}$ sucrose per L, $4.6 \mathrm{~g}$ glycerol per L, and $0.8 \%$ Noble agar). Embryos that were transformed were regenerated on a medium containing MS salts with 20 g sucrose per L, $4.6 \mathrm{~g}$ glycerol per L, $1 \mathrm{~g}$ casein hydrolysate per $\mathrm{L}$, and $0.8 \%$ Noble agar. Elongated embryos were then transferred to a rooting medium supplemented with $0.1 \mathrm{mg}$ BA per $\mathrm{L}, 3 \mathrm{~g}$ activated charcoal per $\mathrm{L}, 1.5 \%$ sucrose, and $0.65 \%$ Bacto agar. A total of 928 independent putative transgenic plants were propagated in the greenhouse. All plants were tested for neomycin phosphotransferase II expression by enzyme-linked immunosorbent assay (ELISA). The presence of transgenes was assessed by polymerase chain reaction and Southern analysis. ELISA revealed various levels of expression of GFLV coat protein in transgenic plants of Couderc 3309. The transgenic rootstocks that have been generated are being screened to determine whether transgenes have conferred resistance to the virus and crown gall diseases.

Key words: somatic embryogenesis; transformation; grapevine fanleaf nepovirus; grapevine leafroll-associated closterovirus3 ; crown gall.

\section{INTRODUCTION}

Grape is one of the most economically important fruit crops worldwide. The United States, with 300000 hectares, is the eighth largest grape grower in the world (Mullins et al., 1992). However, many plant pathogens, such as fungi, bacteria, viruses, and nematodes infect grapes (Pearson and Goheen, 1988) and the resultant diseases can cause serious losses. Among these pathogens, grapevine fanleaf nepovirus (GFLV) and grapevine leafroll-associated closteroviruses (GLRaVs) cause the most important and widespread virus diseases. GFLV is transmitted by the soil-borne nematode Xiphinema index, and GLRaV-3 is transmitted by mealybugs (Engelbrecht and Kasdorf, 1990; Cabaleiro and Segura, 1997; Petersen and Charles, 1997). Nematocides are inefficient for controlling the nematode vec-

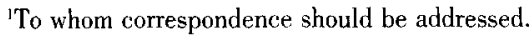

tor of GFLV and recent reports have shown that GLRaV-3 spreads rapidly in vineyards in New Zealand (Petersen and Charles, 1997).

Crown gall, caused by Agrobacterium vitis and to a lesser extent A. tumefaciens, is the most important bacterial disease of grape worldwide (Pearson and Goheen, 1988). Many Vitis vinifera cultivars used for making quality wines and some rootstocks are highly susceptible and may be killed by crown gall. Agrobacterium vitis survives systemically in vines and can be disseminated in symptomless propagation materials. Tumors usually form on lower regions of grape trunks near grafting sites and are initiated following injuries caused by freezing temperatures (Burr and Katz, 1984). No chemical controls are effective for grape crown gall.

Genetic engineering offers an attractive possibility for generating disease-resistant plants; however, transformation of grapevine has been difficult. Recently, transformation of grape was reported (Baribault et al., 1990; Mullins et al., 1990; Le Gall et al., 1994; Nakano et al., 1994; Kikkert et al., 1995; Krastanova et al., 1995; Mauro et 


\begin{tabular}{|c|c|c|c|c|c|c|c|c|}
\hline Genes $^{a}$ & \multicolumn{6}{|c|}{ Constructs $^{b}$} & & \\
\hline 1) LR3.43K & NPTII & \multicolumn{2}{|c|}{ double 35S } & AIMV & GLRaV3-43K & NOS & & \\
\hline 2) LR3cpST & NPTII & $2 \mathrm{enh}$ & $35 \mathrm{~S}$ & AIMV & \multicolumn{2}{|l|}{ GLRaV3-CP } & $35 \mathrm{~S}$ & \\
\hline 3) LR3cpAS & NPTII & 2enh & $35 \mathrm{~S}$ & AIMV & \multicolumn{2}{|l|}{ GLRaV3-CP } & $35 \mathrm{~S}$ & \\
\hline 4) FLcpST & NPTII & 2enh & $35 \mathrm{~S}$ & AIMV & \multicolumn{2}{|l|}{ GFLV-CP } & $35 \mathrm{~S}$ & \\
\hline 5) FLcpAS & NPTII & 2 enh & $35 \mathrm{~S}$ & AIMV & \multicolumn{2}{|l|}{ GFLV-CP } & $35 S$ & \\
\hline 6) FLcp+GUS & NPTII & $35 \mathrm{~S}$ & CMV & \multicolumn{2}{|c|}{ GFLV-CP } & $35 \mathrm{~S}$ & & GUS \\
\hline 7) virE2 delB & NPTII & \multicolumn{2}{|c|}{ double 35S } & AIMV & virE2 del B & NOS & & \\
\hline
\end{tabular}

FIG. 1. Constructs and transgenes used to transform grape rootstocks. All constructs shown lie within the right and left borders of binary vectors. " 1 ) LR3.43K is the GLRaV-3 truncated HSP90-related gene $(43 \mathrm{~K})$ in pBin 19. 2) LR3cpST is the GLRaV-3 sense translatable coat protein gene in pGA482G. 3) LR3cpAS is the antisense form of the GLRaV3 coat protein gene in pGA482G. 4) FLepST is the GFLV sense translatable coat protein gene in pGA482G 5) FLcpAS is the antisense form of the GFLV coat protein gene in pGA482G. 6) FLep + GUS is the GFLV sense translatable coat protein gene in pGA482GG. 7) virE2 del B is from Agrobacterium tumefaciens in pBin19. "From left to right: NPTII, Neomycin phosphotransferase II; 2enh, double cauliflower mosaic virus $35 \mathrm{~S}$ enhancers; $35 \mathrm{~S}$ or double $35 \mathrm{~S}$, CaMV $35 \mathrm{~S}$ promoter; A1MV or CMV, alfalfa mosaic virus or cucumber mosaic virus -C $5^{\prime}$ untranslated leader sequences, respectively; $35 \mathrm{~S}$ or NOS, CaMV $35 \mathrm{~S}$ or nopaline synthase terminators, respectively; GUS $=\beta$-glucuronidase. al., 1995; Scorza et al., 1995, 1996), although relatively few scion and rootstock genotypes were transformed and the regeneration rate has generally been low.

Major objectives of our laboratories are the development of transgenic grapevines that are resistant to viruses and crown gall. In this paper we describe an efficient method for regeneration of plants from somatic embryos of five grape rootstocks. We also report on an improved protocol for Agrobacterium-mediated transformation of somatic embryos of these rootstocks with gene constructs from GFLV, GLRaV-3 and $A$. tumefaciens.

\section{Materials and Methods}

Plant materials. The rootstock cultivars Couderc 3309 (3309C) (V. riparia $\times$ V. rupestris), Vitis riparia 'Gloire de Montpellier' (Gloire), Teleki 5C (5C) (V. berlandieri $\times$ V. riparia), Millardet et De Grasset 101-14 (101-14 MGT) (V. riparia $\times V$. rupestris), and Richter $110(110 R)(V$. rupestris $\times V$. berlandieri) were used in our experiments. Initial embryogenic calluses of Gloire were provided by Mozsar and Süle (Plant Protection Institute, Hungarian Academy of Science, Budapest). All other plant materials came from the vineyard at the New York State Agricultural Experiment Station, Geneva, NY. Callus cultures were initiated from anthers with the methods of Rajasekaram and Mullins (1979). Flower buds of 3309C, 5C, 110R and 101-14 MGT were collected from the vineyard between May 15 and June 30, 1995 and 1996. For Gloire and $3309 \mathrm{C}$, dormant canes were collected from the same vineyard and stored in moist perlite in plastic bags at $4^{\circ} \mathrm{C}$. Two to five node cuttings were rooted in pots with perlite in the greenhouse; floral buds developed within 4 wk and were processed as described below. Buds were removed from the elusters and surface sterilized in $70 \%$ ethanol for $1-2 \mathrm{~min}$. The buds (from greenhouse and field) were transferred to $1 \%$ sodium hypochlorite for $15 \mathrm{~min}$, then rinsed three times in sterile, double-distilled water. Anthers were excised aseptically from flower buds with the aid of a stereomicroscope. The anthers were crushed on a microscope slide under a coverslip with a drop of acetocarmine to observe the cytological stage of pollen (Bouquet et al., 1982). Pollen from different cytological stages for each cultivar were compared to determine which stage was most favorable for callus induction.

Media. Four different solid media were used to produce embryos and to regenerate plants.

(1) Initiation medium. This is an amended MS medium (Murashige and Skoog, 1962) and is referred to as MSE (Mozsar and Süle, 1994). The medium is composed of $20 \mathrm{~g}$ sucrose per $\mathrm{L}, 1.1 \mathrm{mg}$ (2,4-dichlorophenoxyacetic acid) (2,4-D) per $\mathrm{L}$ and $0.2 \mathrm{mg}$ benzyladenine (BA) per $\mathrm{L}$. The $\mathrm{pH}$ was adjusted to
8.5 and Noble agar $(0.8 \%)$ was added before autoclaving. After autoclaving, the medium was cooled to $52^{\circ} \mathrm{C}$ before we added $100 \mathrm{ml}$ of MS basal salts macronutrients solution (Sigma Chemical Co., St. Louis, MO; no. M-0654), $100 \mathrm{ml}$ MS basal salts micronutrient solution (Sigma no. M-0529), and $1 \mathrm{ml}$ of MS vitamin solution (Sigma no. M-3900); the finished medium had a pH of 5.8 .

(2) Differentiation medium. This medium is referred to as HMG (Mozsar and Süle, 1994). The medium is composed of $1 / 2$ MS salts as described above with $10 \mathrm{~g}$ sucrose per $\mathrm{l}, 4.6 \mathrm{~g}$ glycerol per $\mathrm{L}$, and $0.8 \%$ Noble agar.

(3) Regeneration medium. This medium is referred to as MGC medium. It is composed of full-strength MS salts amended with $20 \mathrm{~g}$ sucrose per L, 4.6 g glycerol per L, I g casein hydrolysate per L, and $0.8 \%$ Noble agar.

(4) Rooting medium. This medium is a woody plant medium (MW) (Lloyd and McCown, 1981) supplemented with $0.1 \mathrm{mg}$ BA per L, $3 \mathrm{~g}$ activated charcoal per $\mathrm{L}$, and $1.5 \%$ sucrose. The $\mathrm{pH}$ is adjusted to 5.8 and Bacto agar was added to $0.65 \%$. After autoclaving, the medium was dispensed into sterile baby food jars.

Somatic embryogenesis and regeneration. Anthers were plated under aseptic conditions at a density of 40 to 50 per 9 -cm-diameter petri dish containing MSE. At least 40 plates of anthers were initiated for each rootstock cultivar and plates were cultured at $28^{\circ} \mathrm{C}$ in the dark. Callus was initiated from anthers within $30 \mathrm{~d}$ and after $60 \mathrm{~d}$, embryos were induced. Embryogenic calluses were transferred to hormone-free HMG medium for differentiation. Torpedo stage embryos were next transferred from HMG to MGC medium to promote germination. Cultures were maintained in the dark at $26-28^{\circ} \mathrm{C}$ and transferred to fresh medium at 3-4-wk intervals. Elongated embryos were transferred to rooting medium in baby food jars (5-8 embryos per jar). The embryos were grown in a tissue culture room at $25^{\circ} \mathrm{C}$ with a 16 -h photoperiod $(76 \mu \mathrm{mol} / \mathrm{s})$ to induce shoot and root formation. After plants developed roots, they were transplanted to soil in the greenhouse.

Maintenance and propagation of somatic embryos. Elongated embryos that developed in HMG or MGC medium were cut into 3-4-mm pieces and placed onto MSE medium to promote the development of secondary embryogenic calluses. They were then transferred to HMG for further differentiation and development of new embryos. These secondary embryos on HMG medium could then be transferred to MSE medium to obtain a third cycle of embryogenic calluses and embryos. Fourth and fifth cycles of embryogenic calluses were obtained in the same manner. Alternatively, embryogenic calluses developed from the anthers were propagated on MSE medium to produce sufficient amounts of young embryos for transformation. To maintain cultures, we transferred the embryos at 20-30-d intervals to fresh medium.

Genes and vectors. Seven gene constructs (Fig. 1) were used to transform embryogenic callus from five grape rootstocks. The gene constructs including the coat protein $(c p)$ genes of GFLV and GLRaV-3 (Ling et al., 1997), a 
truncated nonstructural gene representing open reading frame 5 of GLRaV3 (43K) (Ling et al., 1998), and virE2 del B were engineered into three different binary vectors, pGA482GG (Quemada et al., 1991), pGA482G (Jan and Gonsalves, unpublished) and $\mathrm{pBin} 19$. The binary vectors with the transgene were mobilized into A. tumefaciens strains C58sZ707 or LBA4404 by electroporation and were then used for transformation of embryogenic callus.

A. tumefaciens. strain C58 served as the source of the virE2 del B, which is a virE2 derivative that encodes a protein lacking the 215 carboxyl-terminal amino acids of the wildtype VIRE2 protein (Citovsky et al., 1994). The virE2 del B gene was amplified from C58 DNA with the primer set $5^{\prime}$ (TACTTACCATGGATCTTTCTGGCAATGAG), which is identical to the $5^{\prime}$ coding region of the virE2 gene found in the Ti plasmid of C58, and AGATTCCCATGGTCATCTATTTTCGCCAACAAATTCCGCG, which is complementary to nucleotide positions $927-951$ of the same gene.

Transformation. The protocols used for transformation were modified from those described by Scorza et al. (1995). Overnight cultures of Agrobacterium strain C58sZ707 or LBA4404 were grown in LB medium at $28^{\circ} \mathrm{C}$ in a shaking incubator. Bacteria were centrifuged for $5 \mathrm{~min}$ at $3000-5000 \mathrm{rpm}$ and resuspended in MS liquid medium (OD 1.0 at $\mathrm{A}_{600} \mathrm{~nm}$ ). Calluses with embryos were immersed in the bacterial suspension for 15-30 min, blotted dry, and transferred to HMG medium with or without acetosyringone $(100 \mu M)$. Embryogenic calluses were cocultivated with the bacteria for $48 \mathrm{~h}$ in the dark at $28^{\circ} \mathrm{C}$. Then the plant material was washed in MS liquid plus cefotaxime $(300 \mathrm{mg} / \mathrm{ml})$ and carbenicillin $(200 \mathrm{mg} / \mathrm{ml}) 2-3$ times. To select transgenic embryos, we transferred the material to HMG medium containing either 20 or $40 \mathrm{mg}$ kanamycin per $\mathrm{L}, 300 \mathrm{mg}$ cefotaxime per $\mathrm{L}$, and $200 \mathrm{mg}$ carbenicillin per L. Alternatively, after cocultivation, embryogenic calluses were transferred to initiation MSE medium containing $25 \mathrm{mg}$ kanamycin per $\mathrm{L}$ plus cefotaxime and carbenicillin. All plant materials were incubated in dark at $28^{\circ} \mathrm{C}$. After growth on selection medium for 3 mo., embryos were transferred to HMG or MGC without kanamycin to promote elongation of embryos. They were then transferred to rooting medium without antibiotics.In our initial transformation experiments, the transformed embryos that originated from clusters of calli were maintained together on the selection medium. Therefore, some of the embryos that survived the selection possibly resulted from the same transformation event. In subsequent experiments, original clusters of cocultivated embryos were kept separately on the selection medium. In this way, transgenic plants that were generated from a single cluster were known to be independent lines as compared to plants generated from other callus clusters. Nontransformed calluses were grown on the same media with and without kanamycin to verify the efficiency of the kanamycin selection process.

Analysis of transgenic plants. The X-gluc (5-bromo-4-chloro-3-indolyl- $\beta$ glucuronidase) histochemical assay (Jefferson, 1987) was used to detect GUS ( $\beta$-glucuronidase) activity in embryos and plants that were transformed with GFLV-cp plus GUS gene (FLcp + GUS) and that survived kanamycin selection. All regenerated plants were screened with an enzyme-linked immunosorbent assay (ELISA) system (5 Prime-3 Prime, Boulder, CO) to detect the neomycin phosphotransferase II (NPTII) protein in leaf extracts. ELISA tests with coat protein (CP)-specific antibodies were used to assay transgenic plants for GFLV-CP and GLRaV3-CP gene products. ELISA results were read on an SLT.Spectra ELISA reader (Tecan U.S. Inc., Research Triangle Park, NC) at intervals from 15 to 60 min after the substrate was added.

Polymerase chain reaction (PCR) analyses were done to detect the presence of all transgenes in the different grape cultivars. Genomic DNA was isolated from transformed and nontransformed grape plants according to the method of Lodhi et al. (1994). Primer sets included: 1) for GFLV-cp, $5^{\prime}$ primer: etgtaceATGGTCTTTTAAAGTCAGATACC and 3 ' primer: cgtcagtctagaccATGGTGAGAGGATTAGCTGGTAGAGGAG, 2) for GLRaV3-cp, $5^{\prime}$ primer: actatttctagaaccATGGCATTTGAACTGAAATT and $3^{\prime}$ primer: ttctgaggatceatggTATAAGCTCCCATGAATTAT, and 3) for GLRaV-43k, 5' primer: tacttatctagaaccATGGAAGCGAGTCGACGACTA and $3^{\prime}$ primer: tcttgaggatccatggAGAAACATCGTCGCATACTA. Nucleotides in lower case letters of the primers are of nonviral origin to facilitate cloning and expression of the specific gene. PCR detection of virE2 del B was done with the same primers as described before. DNA was initially denatured at $94^{\circ} \mathrm{C}$ for $3 \mathrm{~min}$, then amplified by 35 cycles of $1 \mathrm{~min}$ at $94^{\circ} \mathrm{C}$ (denaturing), $1 \mathrm{~min}$ at $52^{\circ} \mathrm{C}$ (annealing), and $2 \mathrm{~min}$ at $72^{\circ} \mathrm{C}$ (elongation). Amplicons were visualized by electrophoresis in $1.5 \%$ agarose gels.

Southern analyses of selected GFLV-cp and virE2 del B transformants were done with genomic DNA extracted from young leaves of plants $(3309 \mathrm{C})$ as described above. DNA $(10 \mu \mathrm{g})$ was digested with the restriction enzyme $B g l \mathrm{II}$, for GLFV-cp and with PstI for virE2 del B. Cut DNA was electrophoresed on
TABLE 1

REGENERATION EFFICIENCY OF FIVE GRAPE ROOTSTOCKS

\begin{tabular}{lcccc}
\hline Rootstock & Year of initiation & $\begin{array}{c}\text { \% Callus } \\
\text { formation }^{*}\end{array}$ & $\begin{array}{c}\text { \% Embryogenie } \\
\text { callus" }\end{array}$ & $\begin{array}{c}\text { \% Embryos } \\
\text { producing plants }\end{array}$ \\
\hline Gloire & 1996 & 44 & 37 & 56 \\
3309 C & 1996 & 2.5 & 80 & 30 \\
5C & 1995 & 31.6 & 28 & 50 \\
110 R & 1995 & 22 & 19 & 66 \\
101-14 MGT & 1995 & 21 & 15 & 36 \\
\hline
\end{tabular}

"Percent anthers that generated callus. Approximately 2,000 anthers from each cultivar were plated on the initiation medium, MSE.

'Percent callus that formed embryos.

"Percent of embryos from which plants developed.

a $0.7 \%$ agarose gel in Tris-borate-EDTA buffer and transferred to a Genescreen Plus membrane by capillarity in $20 \times \mathrm{SSC}(1 \times$ SCC is $0.15 \mathrm{M} \mathrm{NaCl}$ plus $0.015 M$ sodium citrate). Probe was prepared by random primer labeling (Feinberg and Vogelstein, 1983) of a PCR-amplified GFLV-cp gene coding sequence $(1.5 \mathrm{~kb})$ with radioisotope ${ }^{32}$ P-dATP (DuPont, NEN Research Products, Boston, MA). Prehybridization and hybridization steps were carried out at $65^{\circ} \mathrm{C}$ following the manufacturer's instructions. The autoradiographs were developed after overnight exposure. The probe for virE2 del B was PCR amplified and labeled with a Dig DNA Labeling and Detection Kit (Boehringer Mannheim, Indianapolis, IN) according to the manufacturer's instructions. Prehybridization and hybridization was done at $68^{\circ} \mathrm{C}$.

\section{RESULTS}

Initiation of embryogenic callus and embryogenesis. Calluses of grape rootstocks Gloire, 3309C, 5C, 110R, and 101-14 MGT were initiated on MSE medium. Anthers from flower buds of the five rootstocks began to swell after 1 wk in culture. After $4 \mathrm{wk}$, a smooth, gelatinous, bright yellow callus developed. At this time, some embryos of Gloire, 3309C, and 110R were visible on the callus tissue. After $8 \mathrm{wk}$, calluses were transferred to HMG for further development of embryos. Many embryo clusters were induced from callus by the 8th wk on HMG medium. The percentages of anthers that formed callus, calluses that developed embryos, and embryos that developed plants are shown in Table 1. Embryogenic callus developed well from anthers collected from the field or greenhouse. The highest degree of induction occurred at the T-GPl stages for Gloire (8.4\% of anthers developing embryogenic callus) and 101-14 MGT (4.7\%). Cultivars $3309 \mathrm{C}(18 \%), 5 \mathrm{C}(5.4 \%)$, and $110 \mathrm{R}(2.9 \%)$ were most efficient at the GP1-GP2 stages. At other stages of pollen development the individual cultivars developed none or very few embryogenic calluses.

Plant regeneration. Clusters of embryos developed from callus after cultivation for 8-16 wk on HMG. At the same time, secondary embryos were continually produced from the primary embryos. Embryo clusters were transferred to MGC to increase embryo size and growth rate. However, fewer embryos were produced on MGC than on HMG for all five cultivars. Optimum embryo development of cultivar $110 \mathrm{R}$ was dependent on the use of both media; HMG was required to induce small secondary embryos and MGC was needed to stimulate embryo elongation.

Elongated embryos were transferred onto $\mathrm{MW}$ medium and shoots appeared within 1-2 mo. Plantlets with roots developed from 30$66 \%$ of the embryos that were placed on MW (Table 1). The plantlets were transplanted to soil and kept in the greenhouse. Regenerated plants of Gloire, 5C, 110R, 101-14 MGT, and 3309C exhibited normal morphology. 


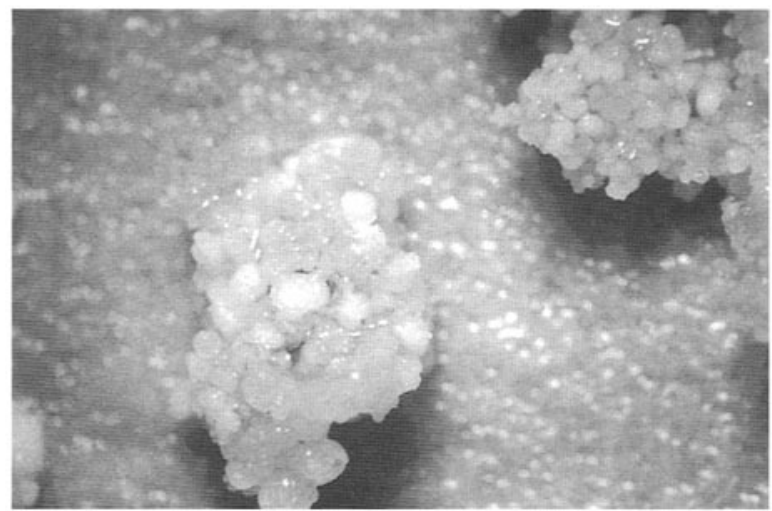

FIG. 2. Grape secondary somatic embryos that were generated from segments of an elongated embryo on MSE medium. This embryogenic stage was used for Agrobacterium-mediated transformation.

Maintenance of somatic embryo culture. A continuous supply of embryogenic callus was produced by an embryo cycling method or by continuous maintenance of callus on MSE. In the former method, embryogenic calluses developed within 2-3 mo. from pieces of elongated embryo that were cultured on the MSE medium. These calluses were particularly suitable for transformation because they developed many uniformly-sized embryos on the MSE medium (Fig. 2). The percentage of embryogenesis for $3309 \mathrm{C}$, Gloire, and 101-14. MGT rootstocks was very high, ranging from $70-90 \%$. In contrast, $5 \mathrm{C}$ produced fewer embryos. Embryogenic calluses of $5 \mathrm{C}$ were produced when the pieces of embryo were cultured on MSE medium for 3 mo., followed by culturing on HMG medium for 2-3 mo. The time required for embryo cycling (embryogenic callus to embryos and back to embryogenic callus) varied with different cultivars; Gloire required 2 3 mo., 3309C and 101-14 MGT required 5-6 mo., and 5C required 6-7 mo. Alternatively, the method to produce embryos by continuous culture of callus on MSE worked very well for 3309C, 101-14 MGT and 110R. Embryos of 5C, however, could not be continuously propagated by this method. Both methods were effective for maintaining embryogenic callus cultures for 2-3 yr.

Transformation. Seven different gene constructs (Fig. 1) were used to transform embryogenic callus. We obtained 928 transgenic plants from the five rootstock cultivars (Table 2). In initial experiments, embryos of Gloire and $110 \mathrm{R}$ were transformed with the GFLV-cp sense + GUS gene construct (FLcp + GUS), and embryo selection was attempted on HMG supplemented with kanamycin at $40 \mathrm{mg} / \mathrm{L}$. However, most embryos died on this medium after 2 mo. Remaining embryos from transformation experiments that had not been cultured on $40 \mathrm{mg}$ kanamycin per $\mathrm{L}$ were transferred to selection medium with kanamycin at $20 \mathrm{mg} / \mathrm{L}$. After $3 \mathrm{mo}$., approximately $2 \%$ of the embryos elongated and developed roots. CUS assays were carried out on these elongated embryos (Fig. $2 \mathrm{~B}$ ); 72\% (36 tested) of Gloire, and 90\% of 1 lOR (100 tested) were GUS positive. In contrast, nontransformed embryos died on the selection medium containing 40 or $20 \mathrm{mg}$ kanamycin per $\mathrm{L}$ after $3 \mathrm{mo}$. Therefore, $20 \mathrm{mg}$ kanamycin per $\mathrm{L}$ was sufficient to inhibit development of nontransformed embryos. Some abnormal-appearing embryos were observed on the selection medium and were put back onto MSE without antibiotics. The elongated embryos obtained by this method showed normal morphology and were
TABLE 2

TRANSFORMATION EFFICIENCY OF FIVE GRAPE ROOTSTOCKS WITH SEVEN GENE CONSTRUCTS

\begin{tabular}{|c|c|c|c|c|c|}
\hline \multirow[t]{2}{*}{ Rootstock } & \multirow[t]{2}{*}{ Gene construct } & \multirow[t]{2}{*}{$\begin{array}{l}\text { No. plants } \\
\text { (lines)" }\end{array}$} & \multirow[t]{2}{*}{$\begin{array}{l}\text { \% NPTII } \\
\text { positivel }\end{array}$} & \multicolumn{2}{|c|}{$\begin{array}{l}\text { Presence of } \\
\text { transgener }\end{array}$} \\
\hline & & & & PCR & Southern \\
\hline $3309 \mathrm{C}$ & virE2 del B & 88 & 100 & + & + \\
\hline Gloire & virE2 del B & 11 & 90 & & \\
\hline $5 \mathrm{C}$ & virE2 del B & 79 & 80 & + & \\
\hline $110 \mathrm{R}$ & virE2 del B & 59 & 97 & + & \\
\hline Gloire & FLcp + GUS & 98 & 95 & + & \\
\hline $110 \mathrm{R}$ & FLcp + GUS & 85 & 100 & + & \\
\hline $3309 \mathrm{C}$ & FLcpST & $171(86)$ & 89 & + & + \\
\hline $101-14 \mathrm{MGT}$ & FLcpST & 91 (29) & 50 & + & + \\
\hline 101-14 MGT & FLcpAS & $79(50)$ & 84 & + & \\
\hline $3309 \mathrm{C}$ & LR3.43K & 88 & 45 & + & \\
\hline $3309 \mathrm{C}$ & LR3cpST & $38(29)$ & 60 & + & \\
\hline $3309 \mathrm{C}$ & LR3epAS & $23(21)$ & 95 & + & \\
\hline Gloire & LR3cpAS & 18 & 88 & + & \\
\hline
\end{tabular}

"Number in parentheses represents minimum number of independent lines, i.e., regenerated from individual callus sections (see Materials and Methods).

"NPTII ELISA tests were carried out on plants that survived kanamycin selection. Samples with absorbance readings at $0 D_{\text {ans }} \mathrm{nm}$ over 0.100 and at least twice that of the nontransformed control plants were regarded as NPTII positives.

'The presence of transgenes was determined (was not done for vir $E 2 \mathrm{del} B$ in Gloire) by PCR (at least 5 plants per cultivar) and for 3 cultivars by Southern analysis.

GUS positive. Therefore, in subsequent transformations, selection was done with $20 \mathrm{mg}$ kanamycin per $\mathrm{L}$.

The efficiencies of transforming embryogenic callus were determined in several experiments. Following transformation of $3309 \mathrm{C}$ embryogenic calluses with the GLRaV-3 $c p$ sense gene (LR3cpST), the calluses were divided into 26 small clusters and placed on HMG selection medium. After 2-3 mo. of kanamycin selection, many small embryos developed in each cluster and embryos were assessed by NPTII ELISA. Transgenic embryos were detected in $92 \%$ of the clusters. In other experiments, 110R, 3309C, 101-14 MGT, and Gloire were transformed with all seven gene constructs. Again, following cocultivation, embryogenic calluses were divided into clusters on MSE selection medium with $20 \mathrm{mg}$ kanamycin per L. After 3-4 mo., new embryogenic calluses were produced and analyzed by NPTII ELISA (Table 2). These assays showed that transformation rates ranged from 45 to $100 \%$ depending on the grape cultivar and experiment.

Elongated embryos (Fig. 2 C) from selection medium were transferred to $\mathrm{MW}$ to produce transgenic plants as previously described. It took 6 to $12 \mathrm{mo}$. after transformation to regenerate transgenic plants with this method. All transgenic plants of the cultivars Gloire, 110R, 5C, 101-14 MGT, and 3309C appeared to be phenotypically normal (Fig 20 ).

Analysis of putative transgenic plants. Gloire and $110 \mathrm{R}$ plants that were transformed with the GFLV-cp sense + GUS gene (FLcp + GUS) constructs and that survived kanamycin selection were analyzed by the GUS assay and by ELISA tests for the expression of GUS, NPTII and GFLV-cp. Seventeen of 23 Gloire plants were GUS and NPTII positive, two were GUS positive but NPTII negative, three were GUS negative but NPTII positive, and one was negative for both genes. For $110 \mathrm{R}, 36$ of 50 tested plants were GUS and NPTII posi- 


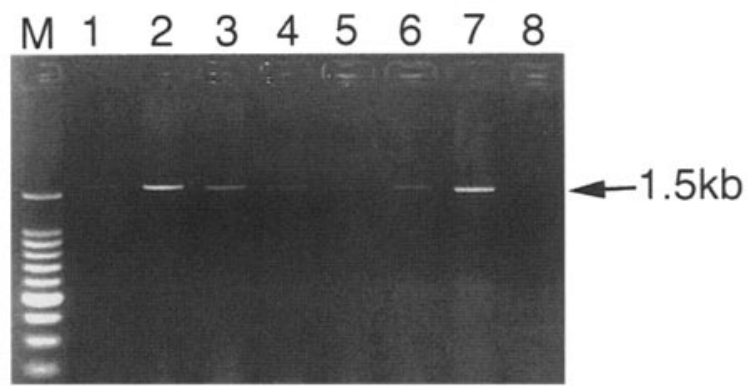

FIG. 3. PCR analysis of grape transgenic $3309 \mathrm{C}$ plants for GFLV-cp gene. Lanes 1-7, Seven lines of transgenic 3309C plants. Lane 8 , A nontransformed $3309 \mathrm{C}$ plant as a negative control. Lane $M$, DNA molecular weight standard of Phix 174 HaeIII fragments.

tive, 13 were GUS negative and NPTII positive, and one was GUS positive and NPTII negative. Expression of the coat protein gene was low in transgenic plants containing this construct (GFLV-cp + GUS) which was not detectable by ELISA. However, PCR analysis showed that 13 of 15 Gloire plants had the GFLV-cp gene (Table 2).

In another experiment, in which GFLV-cp sense construct (FLcpST) was used, expression of GFLV coat protein (CP) was detectable in transgenic $3309 \mathrm{C}$ plants. Of 117 plants that survived kanamycin selection, 114 were ELISA positive for GFLV CP. Among those, 43 plants had low $\mathrm{CP}$ expression $\left(0.1<\mathrm{OD}_{415} \mathrm{~nm}<0.5\right), 35$ had medium $\mathrm{CP}$ expression $\left(0.5<\mathrm{OD}_{405} \mathrm{~nm}<1.0\right)$, and 36 had high $\mathrm{CP}$ expression $\left(\mathrm{OD}_{405} \mathrm{~nm}>1.0\right)$. Nontransformed control plants had $\mathrm{OD}_{4015} \mathrm{~nm}$ readings below 0.002 .

The presence of transgenes in the different cultivars was verified (except for virE2 del B in Gloire) by PCR (Table 2 and Fig. 3). At least five transgenic plants representing known different lines when possible were analyzed by PCR using transgene-specific primers. PCR products of expected sizes were observed in all cases.

Southern blots were done with three cultivars carrying virE2 del B or GFLV-cp transgenes as indicated in Table 2. In all cases, evidence of stable gene insertion was verified. Fig. 4 shows that by Southern analysis, transforming grape rootstocks C3309 and 5C with the virE2 del B gene resulted in multiple lines with different numbers of gene insertions.

\section{DISCUSSION}

Methods for producing and genetically transforming embryogenic callus from five grape cultivars were developed. Embryo culture and regeneration were accomplished with a set of four media. Medium MSE was used for initiation of embryogenic callus from grape anthers, whereas HMG and MGC were used for development of embryos, and MW was used for rooting grape plants. This method of embryo initiation and culture was also effective for regenerating embryos and plants from St. George and SO4 (unpublished data). This is the first report of the transformation of Gloire and $5 \mathrm{C}$ rootstocks, and the development of transgenic grapevines containing the GLRaV-3 $c p$ gene, the truncated GLRaV-3 nonstructural gene $(43 K)$, and the mutant virE2 del B genes.

Several laboratories have reported on the genetic transformation of grape (Baribault et al., 1990; Mullins et al., 1990; Le Gall et al., 1994; Martinelli et al., 1994; Nakano et al., 1994; Kikkert et al., 1995; Krastanova et al., 1995; Mauro et al., 1995; Scorza et al., 1995,

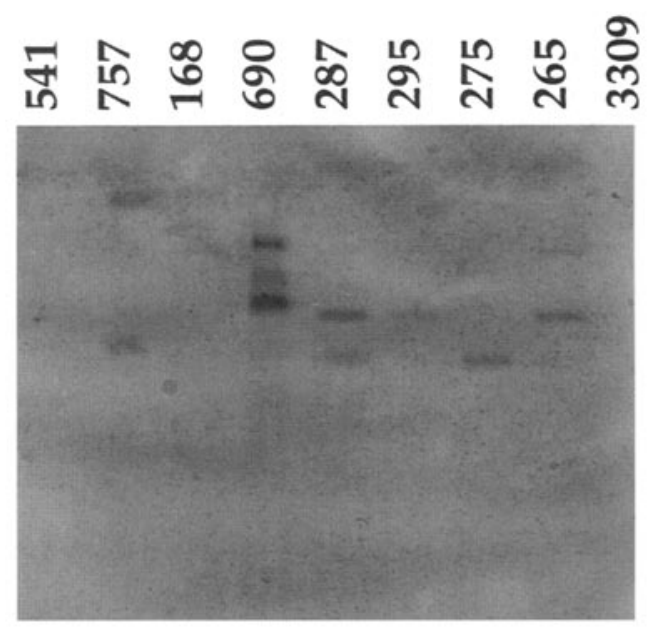

FIG. 4. Southern blot of transgenic grapes carrying the virE2 del B gene. DNA was isolated and digested with PstI and hybridized with the virE2 del $B$ probe as described in the text. Lines $265,275,295,287$, and 168 represent C3309, and 609, 757, and 54l are 5C lines. Lane 3309 represents DNA from nontransformed C3309.

1996). These reports clearly show that transformation of somatic embryogenic cultures is an effective method for producing transgenic grapevines and our work confirms those reports.

In recent yr, grape regeneration has been accomplished with three media, one being hormone-free for embryo development and germination. However, our experiments showed that both HMG and MGC were suitable for embryo development and germination. Mozsar and Viczian (1996) compared the effectiveness of liquid and solid MS medium for increasing the germination rate of embryos of six Vitis cultivars. They showed that germination of somatic embryos of $V$. riparia and V. vinifera cv. Chassela was higher in liquid than in solid medium whereas the reverse was true for $V$. vinifera cv. Szlanka. We found that solid HMG medium was better for embryogenesis, and solid MGC improved the germination rate of embryos. The time required for development from embryo to plant of all five rootstocks can be reduced by $\mathbf{l}$ mo. if embryos are transferred immediately from HMG to MGC medium after formation.

Isolation of anthers at the proper cytological stage is critical for the induction of embryogenic callus. The most efficient stages for induction differed between cultivars. In cases in which tissues at other cytological stages were plated on MSE, callus developed but did not differentiate into embryos. Among the five rootstocks, 3309C anthers yielded relatively few calluses; however, a relatively high percentage were embryogenic.

The maintenance of embryogenic cultures that are suitable for transformation is highly beneficial because it allows one to perform transformations over time. Our embryogenesis cycling method allowed for the maintenance of numerous embryogenic calluses for $21 /$ $2 \mathrm{yr}$. This method should be useful for other grape rootstocks and perhaps for scion cultivars.

Our transformation method was highly efficient for all cultivars tested. We believe that an important factor is to transform callus just before embryogenesis or on callus with small uniform embryos. This conclusion is based on results from 20 transformation experiments.

NPTII ELISA reactions were easily distinguishable and therefore 
were used as a primary criterion for determining whether plants were transgenic. The results in Figure 1 show that not all plants that came through the kanamycin selection were transformed. In two of the experiments (3309C with GLRV-43k and 101-14 MGT with GFLV$c p$ sense) in which selection time was shortened by 1 mo., many nontransformed plants survived the kanamycin selection. Selection at $20 \mathrm{mg} / \mathrm{L}$ level of kanamycin is preferable because at $40 \mathrm{mg} / \mathrm{L}$ embryo formation by transgenic lines is inhibited.

In summary, we have successfully transformed five grape rootstock cultivars with genes from GFLV, GLRaV-3, and A. tumefaciens. Further analyses of all cultivars by additional Southern blotting is essential to determine the numbers of transgene inserts and how they may affect disease resistance phenotypes. The large number of plants that have been generated are being screened for disease resistance. The grape tissue culture and transformation protocols described here may also be applicable to other grape cultivars.

\section{ACKNOWLEDGMENTS}

We thank Iris Velazquez, Hai-Ying Zhu, and Andrew Burr for technical assistance and Joe Ogrodnick and Rob Way for photography. This work was partially funded by Cornell Center for Advanced Technology-Biotechnology Program and ProfiGen Inc.

\section{REFERENCES}

Baribault, T. J.; Skeue, K. G. M.; Cain, P. A.; Scott, N. S. Transgenic grapevines: regeneration of shoots expressing $\beta$-glucuronidase. J. Exp. Bot. 41:1045-1049; 1990.

Bouquet, A.; Piganeau, B.; Lamaison, A. M. Influence du genotype sur la production de cala. dembryoides et plantes entieres par culture dantheres in vitro dans le genre Vitis. C. R. Seances Acad. Sci. Ser. III Sci. Vie. 295:560-574; 1982.

Burr, T. J.; Katz, B. H. Grapevine cuttings as potential sites of survival and means of dissemination of Agrobacterium tumefaciens. Plant Dis. 68:976-978;1984.

Cabaleiro, C.; Segura, A. Field transmission of grapevine leafroll associated virus 3 (GLRaV-3) by the mealybug Planococcus citri. Plant Dis. 81:283-287; 1997.

Citovsky, V.; Warnick, D.; Zambrysk, P. Nuclear import of Agrobacterium VirD2 and VirE2 proteins in maize and tobacco. Proc. Natl. Acad. Sci. USA 91:3210-3214; 1994.

Engelbrecht, D. J.; Kasdorf, G. G. F. Transmission of grapevine leafroll disease and associated closteroviruses by the vine mealybug planococcus ficus. Phytophylactica 22:341-346; 1990.

Feinberg, A. P.; Vogelstein, B. A technique for radiolabeling DNA restriction endonuclease fragments to high specific activity. Anal. Biochem. 132:6-13; 1983.

Jefferson, R. A. Assaying chimeric genes in plants: the GUS gene fusion system. Plant Mol. Biol. Rep. 5:387-405; 1987.

Kikkert, J. R.; Hebert-Soul, D.; Wallace, P. G.; Striem, M. J.; Reisch, B. I. Transgenic plants of 'Chancellor' grapevine (Vitis sp.) from biolistic transformation of embryogenic cell suspensions. Plant Cell Rep. 15:311-316; 1995.

Krastanova, S.; Perrin, M.; Barbier, P.; Demangeat, G.; Cornuet, P.; Bardonnet, N.; Otten, L.; Pinck, L.; Walter, B. Transformation of grapevine rootstocks with the coat protein gene of grapevine fanleaf nepovirus. Plant Cell Rep. 14:550-554; 1995.
Le Gall, O.; Torregosa, L.; Danglot, Y.; Candresse, T.; Bouquet, A. Agrobacterium-mediated genetic transformation of grapevine somatic embryos and regeneration of transgenic plants expressing the coat protein of grapevine chrome mosaic nepovirus (GCMV). Plant Sci. 102:161$170 ; 1994$.

Ling, K.-S.; Zhu, H.-Y.; Alvizo, H.; Hu, J. S.; Drong, R. F.; Slightom, J. L.; Gonsalves, D. The coat protein gene of grapevine leafroll associated closterovirus-3: cloning, nucleotide sequencing and expression in transgenic plants. Arch. Virol. 142:1 101-1116; 1997.

Ling, K.-S.; Zhu, H.-Y.; Drong, R. F.; Slightom, J. L.; McFerson, J. R.; Gonsalves, D. Nucleotide sequence of the $3^{\prime}$ terminal two-thirds of the grapevine leafroll-associated virus-3 genome reveals a typical monopartite closterovirus. J. Gen. Virol. 79:1299-1307; 1998.

Lloyd, G.; McCown, B. H.Commercially feasible micropropagation of mountain laurel, Kalmia latifolia, by use of shoot tip culture. Proc. Int. Plant Prop. Soc. 30:421-427; 1981.

Lodhi, M. A.; Ye, G. N.; Weeden, N. F.; Reisch, B. I. A simple and efficient method for DNA extraction from grapevine cultivars and Vitis species. Plant Mol. Biol. Rep. 12:6-13; 1994.

Martinelli, L.; Mandolino, G. Genetic transformation and regeneration of transgenic plants in grapevine (Vitis rupestris S.). Theor. Appl. Genet. 88:62l-628; 1994.

Mauro, M. C.; Toutain, S.; Walter, B.; Pink, L.; Otten, L.; Coutos-Thevenot, P.; Deloire, A.; Barbier, P. High efficiency regeneration of grapevine plants transformed with the GFLV coat protein gene. Plant Sci. 112:97-106; 1995.

Mozsar, J.; Süle, S. A rapid method for somatic embryogenesis and plant regeneration from cultured anthers of Vitis riparia. Vitis 33:245-246; 1994.

Mozsar, J.; Viczian, O. Genotype effect on somatic embryogenesis and plant regeneration of Vitis spp. Vitis 35:155-157; 1996.

Mullins, M. G.; Bouquet, A.; Williams, L. E. Biology of the grapevine. Cambridge: Cambridge University Press; 1992.

Mullins, M. G.; Tang, F. C. A.; Facciotti, D. Agrobacterium-mediated genetic transformation of grapevines: transgenic plants of Vitis rupestris Scheele and buds of Vitis vinifera L. Bio/Technology 8:1041-1045; 1990.

Murashige, T.; Skoog, F. A revised medium for rapid growth and bioassays with tobacco tissue culture. Physiol. Plant. 15:473-497; 1962.

Nakano, M.; Hoshino, Y.; Mii, M. Regeneration of transgenic plants of grapevine (Vitis vinifera L.) via Agrobacterium rhizogenes-mediated transformation of embryogenic calli. J. Exp. Bot. 45:649-656; 1994.

Pearson, R. C.; Goheen, A. C. Compendium of grape diseases. St. Paul, MN: APS Press; 1988.

Petersen, C. L.; Charles, J. G. Transmission of grapevine leafroll-associated closteroviruses by Pseudococcus longispinus and $P$. calceolariae. Plant Pathol. 46:509-515; 1997.

Quemada, H. D.; Gonsalves, D.; Slightom, J. L. CMV-C coat protein gene expression in tobacco: protection against infection by CMV strains transmitted mechanically or by aphids. Phytopathology $81: 794-802$; 1991.

Rajasekaram, K.; Mullins, M. G. Embryos and plants from cultured anthers of hyploid grapevines. J. Exp. Bot. 30:399-407; 1979.

Scorza, R.; Cordts, J. M.; Ramming, D. W.; Emershad, R. L. Transformation of grape (Vitis vinifera L.) zygotic-derived somatic embryos and regeneration of transgenic plants. Plant Cell Rep. 14:589-592; 1995.

Scorza, R.; Cordts, J. M.; Gray, D. J.; Gonsalves, D.; Emershad, R. L.; Ramming, D. W. Producing transgenic 'Thompson Seedless' grape (Vitis vinifera L.) plants. J. Am. Soc. Hortic. Sci. 121:616-619; 1996. 